This item was submitted to Loughborough's Research Repository by the author.

Items in Figshare are protected by copyright, with all rights reserved, unless otherwise indicated.

\title{
Book review: The Birth of Territory
}

PLEASE CITE THE PUBLISHED VERSION

http://dx.doi.org/10.1177/0309132514567573

PUBLISHER

(c) The Author. Published by Sage

VERSION

AM (Accepted Manuscript)

\section{PUBLISHER STATEMENT}

This work is made available according to the conditions of the Creative Commons Attribution-NonCommercialNoDerivatives 4.0 International (CC BY-NC-ND 4.0) licence. Full details of this licence are available at: https://creativecommons.org/licenses/by-nc-nd/4.0/

\section{LICENCE}

CC BY-NC-ND 4.0

\section{REPOSITORY RECORD}

Antonsich, Marco. 2019. "Book Review: The Birth of Territory”. figshare. https://hdl.handle.net/2134/21002. 
Stuart Elden, The Birth of Territory. Chicago: University of Chicago Press, 2013; 493 pp.: 9780226202570, US\$30.00 (pbk)

This is an extraordinary book, both for the time it took to see the light (about twelve years of work, on and off) and for its ambitious aim: nothing less than "[to] re-inscribe the history of space both in the history of political theory and in the history of the state” (p. 15). Formed by nine chapters, the book starts its historical journey with ancient Greece and ends with $17^{\text {th }}$ century political thinkers. According to Elden (p. 15), whoever came after this period worked within the framework of state-territorial politics. This statement implicitly explains the book's title and time coverage. In other words, Elden's focus is not on territory as we know it today, but on what predated it and made it happen. Chapter 1 discusses the notion of polis, mainly through a reading of Plato and Aristotle and an analysis of Kleisthenes's urban reforms of Athens. Chapter 2 explores Roman political thinking, with a discussion of key spatial terms such as territorium, limes, and fines, investigated through the works mainly by Julius Caesar, Cicero and Tacitus. Chapter 3 initiates what is a major theme in the book, namely the relation between religious and secular powers, which are analysed in this chapter through Saint Augustine's distinction between civitas Dei and civitas terrena. The same chapter then moves to review the work by Boethius and Isidore of Seville, continues with a reading of the histories of 'barbarian' tribes by Paul the Deacon, Gregory of Tours, Jordanes, and Bede, and concludes with an analysis of the Old English poem Beowulf. Here, like elsewhere in the book, the reader is somewhat left wondering what the connections between all these texts are. Certainly this might be due to the huge amount of literature surveyed, but the criteria for selecting these texts and the links between them could have been further specified. Chapter 4, 5 and 6 also address the above mentioned theme of religious and secular power, with a discussion, among others, of The Donation of Constantine, the translatio imperii under Charlemagne, the reconciliation of Aristotle with Christianity in Thomas Aquinas and the struggle between pope Boniface VIII and Philip the Fair of France, which sets the context for discussing the works of Dante, Marsilius of Padua and William of Ockham. In between, Elden also manages to write separate sections on Roman cartography and feudalism, which again read like self-standing fragments, in need of being recomposed within a well-articulated argument.

The actual birth of territory only comes in chapter 7, when Elden discusses the rediscovery of Roman law in the texts of Bartolus of Sassoferrato and Baldus de Ubaldis. They are those who first introduced territorium in a modern sense, i.e. as a portion of the Earth over which 
political power exercises its exclusive jurisdiction. Chapter 8 and 9 condense about two hundred years of political theorization, by looking at the relation between place and power in authors such as Machiavelli, Martin Luther, Bodin, and Botero (with a literary excursus on Shakespeare) and authors associated with the scientific revolution, such as Descartes and Leibniz, besides key political theorists such as Locke and Hobbes.

Covering about two-thousand-year of political history, the book is certainly an extraordinary intellectual endeavour which does not go, however, without limitations. As already mentioned, often chapters, sections and even paragraphs seem disconnected. This matters not so much stylistically, but in terms of clarity of argument. This point, along with tendency to amass a huge amount of historical information with relatively scattered interpretation, makes the reader wondering what to make, at the end, of all this information. The fact that it is also organized chronologically, author by author, rather than thematically does not help the reader understand what really matters and why. Moreover, given the huge time span and the limited space, the book might risk reproducing what we already know about certain key-notions, rather than offering innovative readings. I am thinking, for instance, of limes, which finds in other authors (e.g., Sordi, 1987) a more encompassing investigation. My major criticism, though, is twofold. First, this is not a book on territory or better it is also on territory. Elden explicitly mentions that it is a book on the relation between place and power (p. 16), but at times it is only political power and its expressions (e.g., regnum, dominium, imperium) which are discussed. True, these unavoidably bear a spatial connotation, but this latter is not always central in Elden's analysis. Thus, The Birth of Territory might not look much different from other books on the history of political theory - Sabine (1973) comes first to my mind, also due the kind of authors and the order in which they are discussed. Elden acknowledges (p. 17) that the question of territory or the broader notion of the place of power might seem at times to disappear from the book. Yet, despite this caveat, he does not seem to offer solid directions to the reader for avoiding getting lost in lengthy historical accounts where notions of territory, place, or space are either missing or hidden. Second, despite Elden affirms (p. 7) that "territory is a word, a concept, and a practice", the book largely remains an erudite piece of textual analysis. The focus is on territory as a word and in fact it is not surprising that, conceptually, the book does not seem to offer newer insights than what his Author has already disclosed elsewhere (e.g., Elden, 2010). Once again Elden is aware of this limit (p. 323), but he is strangely dismissive, for instance, of Teschke's work (2003), whose focus is exactly on states' territorial practices. Elden accuses Teschke of being terminologically vague and imprecise (p. 310) and yet it is exactly thanks to Teschke that we can put Elden's textual 
work in context and observes the temporal mismatch between the birth of territory as a word and its operationalization by the modern state (something which goes indeed missed in Elden's textual account).

Overall, this is certainly an opus magnum for its intellectual breadth. I am fascinated by the capacity of one person to master such an extensive literature. The book will surely offer a basis for further historical investigations into the notion of territory or more broadly the relation between space/place and politics.

Marco Antonsich

\section{References:}

Elden S (2010) Land, terrain, territory. Progress in Human Geography, 34(6): 799-817.

Sabine GH (1973) A history of political theory. London: Holt.

Sordi M (ed.) (1987) Il confine nel mondo classico. Milan, Vita Pensiero.

Teschke B (2003) The myth of 1648. London: Verso. 